\section{Vage teorier}

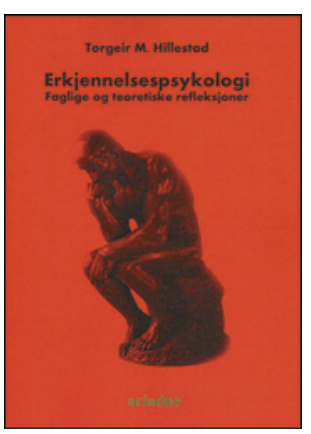

Torgeir M. Hillestad

Erkjennelsespsykologi

Faglige og teoretiske refleksjoner. 158 s.

Oslo: Ariadne Forlag, 2013. Pris NOK 249 ISBN 978-82-90477-48-1
Forfatteren er ansatt ved Universitetet i Stavanger og har en doktorgrad i psykologi. Hovedmålet med utgivelsen er «å tilveiebringe ny grunnlagsinnsikt når det gjelder psykologien». Det er høye mål, og jeg kan dessverre ikke se at forfatteren har innfridd sine ambisjoner. Mye av teksten vies psykiatriske spørsmål, men psykologiens grunnlagsproblemer omfatter vel langt mer enn psykiatrien? Og hva mener egentlig forfatteren med erkjennelsespsykologi? Det får vi ikke noe godt svar på.

Boken har sju kapitler. Kapittel 1 om «realisme som vitenskapsteoretisk posisjon» i psykologien er ikke lett å forstå fordi forfatteren ikke redegjør klart for hva han forstår med realisme. Dermed blir diskusjonen av empirisme og konstruktivisme som motpol til realismen vanskelig å få grep om. I neste kapittel drøftes den kritikken mot psykologien som er kommet fra sosialt hold, en kritikk som hevder at psykologien generelt er for individualistisk. Kapittel 3 , «Diagnosens status og rolle», tar opp velkjente problemer. Forfatteren polemiserer mot de stadig nye diagnosene i psykiatrien og er tilhenger av en dimensjonal diagnostikk. Mange av oss har sett med uro på den overdiagnostisering av «normale» atferdsmønstre som er i ferd med å skje, særlig innen amerikansk DSM-diagnostikk. De fleste fagfolk vil også være enige om at en dimensjonal diagnostikk er mer vitenskapelig enn en kategorisk sådan. Men i vanlig psykiatrisk klinisk arbeid er en kategorisk klassifikasjon tross alt enklere å anvende. I kapittel 5, «Psykologi og politisk ideologi», vil forfatteren blant annet «kritisere to overordnede politisk-ideologiske prinsipper eller forutsetninger som faktisk utmeislede sentrale ideologier bygger på, nemlig kollektivisme og individualisme». Her er forfatteren innom både Aristoteles, Thomas Hobbes, David Hume og John Stuart Mill uten at man blir særlig klokere av det. I et kapittel om hatets psykologi er han opptatt av Philip Zimbardos fengselseksperiment, som antydet at de fleste av oss vil oppføre oss som destruktive bødler hvis omstendighetene er til stede. Boken avsluttes med et kapittel om altruisme.

Forfatteren er i forskjellige kapitler innom anti-psykiatere som Thomas Sazs, David Cooper og Ronald Laing, og hjemlige psykologer som Ole Jacob Madsen og Tor-Johan Ekeland og filosofer som Arne Johan Vetlesen og Lars Svendsen som han både støtter og polemiserer mot. Men kritikken er ofte vag, noe som gjør det vanskelig å vite hva forfatteren selv mener. Lange, til dels kompliserte setninger florerer, og de mange skrivefeil irriterer. Jeg tror neppe psykologer og psykiatere, eller psykologistudenter og den «interesserte almenhet» som forfatteren også appellerer til, vil finne boken særlig interessant, dessverre.

\section{Einar Kringlen}

Professor emeritus, Psykiatrisk institutt, Vinderen

Universitetet i Oslo

\section{Manual i gruppeterapi for barn}

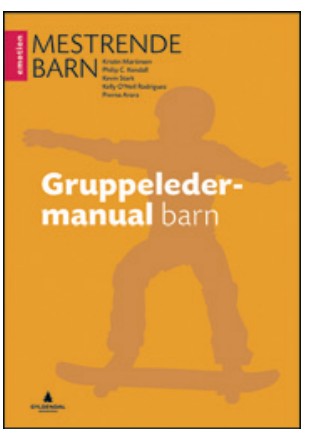

Kristin Martinsen Mestrende barn

Gruppeledermanual barn. 123 s, tab, ill. Oslo: Gyldendal Akademisk, 2014. Pris NOK 325 ISBN 978-82-05-46053-9

Programmet «Mestrende barn» er et lavterskeltilbud rettet mot barn i alderen 8-13 år med symptomer på angst og depresjon. Det er basert på kognitiv atferdsterapi og er utviklet med utgangspunkt i Philip Kendalls Coping Cat-program for angst og Kevin Starks ACTION-program for depresjon. Målsettingen med programmet er å redusere risikoen for at barna utvikler en angstlidelse eller en depressiv lidelse. Programmet omfatter et gruppetilbud for barn og foreldre, der barna møter til gruppesamtaler over ti uker, mens foreldrene møtes til samlinger parallelt.

Programmet «Mestrende barn» består i tillegg til denne boken av tre andre bøker: Arbeidsbok barn, Gruppeledermanual foreldre og Arbeidsbok foreldre.

Gruppeledermanual barn beskriver time for time de 20 trinnene i behandlingen. Sentrale komponenter er psykoedukasjon, øvelser i mestringsstrategier og problemløsning, kognitiv restrukturering og atferdsbaserte strategier. Den første halvdelen av programmet (10 timer) brukes til å lære disse ferdighetene, mens den andre tar sikte på å fokusere på det enkelte barns spesifikke problem. Manualen er bygd opp med faste punkter for hver time. Hver time beskrives i en 3-4 siders lang tekst med gode illustrasjoner i form av tegninger og figurer. Boken har to vedlegg med forslag om terapeutiske aktiviteter basert på spill og lek, og mulige eksponeringsøvelser for engstelige barn. Fremstillingen er god og oversiktlig, og den gir en grei oppskrift på hvordan man skal lede de enkelte timene.

En svakhet ved manualen er at den ikke drøfter hvordan man skal rekruttere de barna man mener kan ha nytte av programmet. Skal det skje via helsesøster, skolepsykolog fastlege eller foreldre? Dette er viktig fordi sammensetningen av grupper er av stor betydning for resultatet av behandlingen. Jeg savner også en redegjørelse for hvilken bakgrunnskunnskap man mener gruppelederne bør ha. Selv om manualen gir mange praktiske råd og strukturerer terapien, er det viktig at de personene som leder gruppene, har kunnskap om barns psykologi og hvilke gruppeprosesser som kan utvikle seg. Effekten av kognitiv terapi er avhengig av høy terapeutkompetanse. Veiledning av gruppelederne, noe som er av stor betydning for vellykket behandling, er heller ikke tatt opp.

Med dagens beskjedne tilgang på kompetente terapeuter i kognitiv terapi i primærhelsetjenesten og i skolen er det vanskelig å se at dette behandlingsprogrammet kan få noen stor utbredelse. Og det er synd for programmet er godt, men det trengs kompetente fagpersoner for å gjennomføre det.

\section{Tone Tangen}

Professor i psykiatri, Universitetet i Bergen 